\title{
Air Polluted Environment and Health Effects
}

\author{
Michael Theophanides, Jane Anastassopoulou and \\ Theophile Theophanides \\ National Technical University of Athens, Chemical Engineering School, \\ Radiation Chemistry \& Biospectroscopy,
}

Greece

\section{Introduction}

\subsection{The general problem of pollution}

The natural environment in which we live in is ever-increasingly threatened by human activity (Theophanides, M. et al 2002). Both the inhabited and uninhabited environment is threatened and one such indication is the changes of the climate (Theophanides, T. et al. 2002). Furthermore, as of 2006, the International Union for Conservation of Nature and Natural Resources (IUCN) Red List contains over 15,000 species threatened with extinction (M. Theophanides et al. 2007, 2007, Touloumi et al. 1994, Katsouyanni 2003, ArribasMonzón, et al. 2001, 1998, Yang, et al. 2004; Kotzias, 2003). The assessment includes species from a broad range of taxonomic groups including vertebrates, invertebrates, plants, and fungi. Human health is threatened with diseases and early mortality and is even more prevalent in emerging economies facing rapid industrialization. There is increasing evidence that global warming also contributes to a higher rate of disease growth and propagation. Epidemiological studies (The MACBETH project 1999: IT070, Jerrett M. et al 2004; Samoli E.et al 2003, Tunnicliffe et al. 2003; Filleul L, et al 2003, Basu R. \& Samet J. M., 2002, Le Tertre A. et al. 2002, Dominici F., 2002, Sunyer \& Basagana 2001) of occupational diseases on the working population are showing the ill effects of the environment on people working in a contaminated environment over a lifetime of employment. The study of occupational diseases is becoming an ever-increasing problem to be investigated (Kunzli 2001). The social and economic (Kunzli 2001) evolution inevitably produced stress situations in the environment resulting in population density increases that were difficult to handle efficiently using existing infrastructures and continuing increasing urbanization of cities. On the other hand, while we are quite aware of the sources of pollution, a great deal of research is still needed to recognize the effects on health, the climate, extinguishing species and their role in the evolutionary and food-supply chain. We must also educate individual citizens about pollution - starting with even the simplest of things such as recycling, reducing their dependency on the automobile, and not littering.

Exposure to pollution from gaseous pollutants diminishes the quality of atmospheric air that we breathe can induce diseases and deaths in increased numbers in the population when the values of pollutants are exceeding the recommended safe thresholds. The most vulnerable to such effects are the elderly, children and those already afflicted with health problems. 
Several studies (M. Theophanides et al. 2007, 2007, Touloumi et al. 1994, Katsouyanni 2003, Katsouyanni et al. 1997, Ballester, et al 1996, Arribas-Monzón, et al. 2001) indicated a positive association of sulfur dioxide $\left(\mathrm{SO}_{2}\right)$ and nitrogen oxide $\left(\mathrm{NO}_{2}\right)$ with mortality - $\mathrm{NOx}$ being one of the principal emissions of aviation industry. Benzene is a well-known carcinogen (Touloumi et al. 1994 ) depending on the degree of exposure, and can affect persons with indoor or outdoor air exposure for which the risk of death can be higher. A number of studies in recent years substantiate the detrimental effect of environmental pollution on human health, disease and pollution (Theophanides, M. 2002, 2007; Touloumi et al. 1994, Katsouyanni 2003, Katsouyanni et al. 1997, Ballester, et al 1996, Arribas-Monzón, et al. 2001).

\subsection{What is air quality?}

"Air Quality" is a measure of the degree of ambient atmospheric pollution, relative to the potential to inflict harm on the environment. The potential for deterioration and damage to both public health and the environment, through poor air quality, has been recognized at a legislative and international level. Air pollution is often quantified for purposes of comparison or threshold attainment using the Air Quality Index (AQI).

The Air Quality Index (AQI) has been developed by the Environmental Protection Agency (EPA) USA, to provide accurate, information about daily levels of air pollution. The Index provides organizations with a standardized system of measuring pollution levels for the major air pollutants that are regulated. Index figures enable the public to determine whether air pollution levels in a particular location are Good, Moderate, Unhealthy for Sensitive Groups or worse. In addition, EPA and local officials use the AQI as a public information tool to advise the public about the general health effects associated with different pollution levels and to describe whatever precautionary steps may need to be taken if air pollution levels rise into the unhealthy range.

The EPA uses the Air Quality Index to measure five major pollutants for which it has established National Ambient Air Quality Standards under the Clean Air Act (Tobias et al. 2001). The pollutants are particulate matter, sulfur dioxide, carbon monoxide, nitrogen dioxide and ground level ozone. For each of the five pollutants, EPA has established air quality standards protecting against health effects that can occur within short periods of time (a few hours or a day). For example, the standard for sulfur dioxide - that is, the allowable concentration of this pollutant in a community's air - is 0.14 parts per million measured over a 24-hour period. Air concentrations higher than 0.14 parts per million (ppm) exceed the national standard. For ozone, the 8-hour average concentration permitted under the standard is 0.085 parts per million (ppm).

In the USA, the AQI is calculated every hour for each air quality parameter according to the following formula (Coull, 2001):

$$
\mathrm{AQI}=\frac{\mathrm{I}_{\mathrm{HI}}-\mathrm{I}_{\mathrm{LO}}}{\mathrm{BP}_{\mathrm{HI}}-\mathrm{BP}_{\mathrm{LO}}} \mathrm{X}\left(\mathrm{C}_{03}-\mathrm{BP}_{\mathrm{LO}}\right)+\mathrm{I}_{\mathrm{LO}}
$$

$\mathrm{AQI}=$ Air Quality Index, $\mathrm{I}_{\mathrm{LO}}=$ Index at the lower limit of the AQI category, $\mathrm{I}_{\mathrm{HI}}=$ Index at the upper limit of the AQI category

$\mathrm{BP}_{\mathrm{LO}}=$ Break-point concentration at lower limit of the $\mathrm{AQI}$ category, $\mathrm{BP}_{\mathrm{HI}}=$ Break-point concentration at upper limit of the $\mathrm{AQI}$ category, $\mathrm{C}_{\mathrm{O} 3}=8$-hour ozone concentration 


\begin{tabular}{|c|c|c|c|}
\hline Parameter & Concentration & Units & AQI Formula \\
\hline \multirow{2}{*}{ Carbon Monoxide } & If $>13$ & \multirow{2}{*}{ ppm } & $\mathrm{AQI}=(1.47 \times$ concentration $)+5.88$ \\
\hline & If $<=13$ & & $\mathrm{AQI}=1.92 \times$ concentration \\
\hline \multirow{3}{*}{ Ozone } & If $<=.05$ & \multirow{3}{*}{ ppm } & $\mathrm{AQI}=500 \times$ concentration \\
\hline & If $>.05<=.08$ & & $\mathrm{AQI}=(833 \times$ concentration $)-16.67$ \\
\hline & If $>.08$ & & AQI $=(714 x$ concentration $)-7.14$ \\
\hline Sulfur Dioxide & All & ppm & AQI $=147.06 \times$ concentration \\
\hline \multirow{2}{*}{ Nitrogen Dioxide } & If $<=0.21$ & \multirow{2}{*}{ ppm } & $\mathrm{AQI}=238.09 \times$ concentration \\
\hline & If $>0.21$ & & $\mathrm{AQI}=(156.24 \times$ concentration $)+17.19$ \\
\hline \multirow{2}{*}{ PM2.5 } & If $<=30$ & \multirow{2}{*}{$\mathrm{ug} / \mathrm{m}^{3}$} & $\mathrm{AQI}=0.8333 \times$ concentration \\
\hline & If $>30$ & & $\mathrm{AQI}=(0.5 \times$ concentration $)+10$ \\
\hline
\end{tabular}

Table 1. Air Quality Index Formula

Table 2 illustrates the likely health effects from various levels of AQI based on the US standards:

\begin{tabular}{|c|c|c|c|}
\hline AQI Range & $\begin{array}{l}\text { EPA Color } \\
\text { Scale }\end{array}$ & $\begin{array}{l}\text { EPA } \\
\text { Descriptor }\end{array}$ & Clean Air Campaign Health Advisory \\
\hline 0 to 50 & Green & Good & $\begin{array}{l}\text { The air quality is good and you can engage in } \\
\text { outdoor physical activity without health concerns. }\end{array}$ \\
\hline 51 to 100 & Yellow & Moderate & $\begin{array}{l}\text { At this level the air is probably safe for most people. } \\
\text { However, some people are unusually sensitive and } \\
\text { react to ozone in this range, especially at the higher } \\
\text { levels (in the } 80 \text { s and } 90 \mathrm{~s} \text { ). People with heart and lung } \\
\text { diseases such as asthma, and children, are especially } \\
\text { susceptible. People in these categories, or people who } \\
\text { develop symptoms when they exercise at "yellow" } \\
\text { ozone levels, should consider avoiding prolonged } \\
\text { outdoor exertion during the late afternoon or early } \\
\text { evening when the ozone is at its highest. }\end{array}$ \\
\hline 101 to 150 & Orange & $\begin{array}{l}\text { Unhealthy } \\
\text { for Sensitive } \\
\text { Groups }\end{array}$ & $\begin{array}{l}\text { In this range the outdoor air is more likely to be } \\
\text { unhealthy for more people. Children, people who } \\
\text { are sensitive to ozone, and people with heart or lung } \\
\text { disease should limit prolonged outdoor exertion } \\
\text { during the afternoon or early evening when ozone } \\
\text { levels are highest. }\end{array}$ \\
\hline 151 to 200 & Red & Unhealthy & $\begin{array}{l}\text { In this range even more people will be affected by } \\
\text { ozone. Most people should restrict their outdoor } \\
\text { exertion to morning or late evening hours when the } \\
\text { ozone is low, to avoid high ozone exposures. }\end{array}$ \\
\hline 201 to 300 & Purple & $\begin{array}{l}\text { Very } \\
\text { Unhealthy }\end{array}$ & $\begin{array}{l}\text { Increasingly more people will be affected by ozone. } \\
\text { Most people should restrict their outdoor exertion to } \\
\text { morning or late evening hours when the ozone is } \\
\text { low, to avoid high ozone exposures. }\end{array}$ \\
\hline Over 300 & Black & & Everyone should avoid all outdoor exertion. \\
\hline
\end{tabular}

Table 2. Air Quality Index threshold levels (EPA) 
A simplified version of AQI is shown in Table 1(Coull, 2001). The highest number calculated for a specific hour is used as the AQI for that hour and indices range from 0 to $100 \%$. Calculating the general equation for specific pollutants results in the pollutant AQI shown in Table 1.

The AQI places maximum emphasis on acute health effects occurring over very short time periods - 24 hours or less - rather than chronic effects occurring over months or years. By notifying the public when an AQI value exceeds 100, citizens are given an adequate opportunity to react and take whatever steps they can to avoid exposure. The approach EPA follows is conservative, because (1) each standard has built into it a margin of safety that is designed to protect (1) highly susceptible people, and (2) the public notice is triggered as soon as a single sampling station in the community records an AQI level that exceeds 100 .

Finally, the AQI does not take into account the possible adverse effects associated with combinations of pollutants (synergism). As more research is completed in the future, the AQI may be modified by EPA to include such effects.

\subsection{What is air pollution numerical simulation?}

Numerical Simulation of Air Pollution is the attempt to predict or simulate, by numerical means, the ambient concentration of criteria pollutants found within the atmosphere of a domain. The principal application of air pollution modeling is to investigate air quality scenarios so that the associated environmental impact on a selected area can be predicted and quantified. It is important in several ways (Coull 2001).

i. To aid in the evaluation of source-receptor relationships so that responsibility for specific impacts can be apportioned.

ii. To aid in project planning, site evaluation and/or environmental impact of present/future sources.

iii. To enable the evaluation of existing sources in relation to compliance with legislation.

iv. To permit the evaluation of proposed abatement and control strategies, in relation to short and/or long term issues.

v. To permit the assessment of episodic tactics and disaster aversion strategies

vi. To optimize emission inventories and operating conditions while ensuring compliance with legislative controls.

It was possible to compare the results of simulation data with the specific air data that had been calculated in an area and correlates with pollution levels of the region. The Geographical Information Systems (GIS) was applied to this type of analysis in order to organize data results. This study integrates atmospheric simulation chemical data collected in various forms and emissions data into a GIS environment. In the study gas samples were collected and added to the GIS database. High resolution GIS models were created for a few regions where various types of atmospheric simulation studies were conducted. The dispersion of combined pollutants $\mathrm{NO}_{x}$, VOCs, Benzene, PM is shown in Fig. 1.

The dark red corresponds to higher levels of pollutants and indicates the dispersion along the industries and agricultural lands from the point of pollutant sources. The dispersion direction depends on atmospheric conditions. 


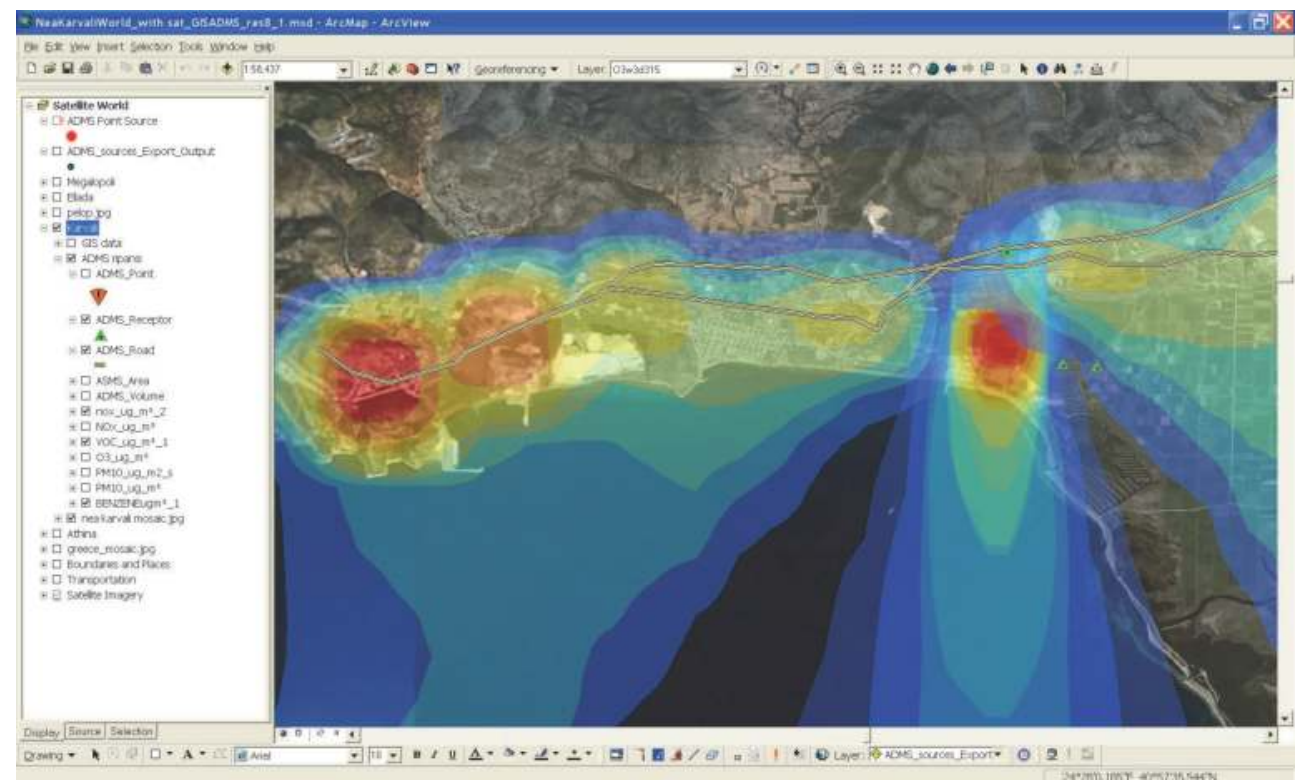

Fig. 1. Numerical simulation of pollution dispersion including all factors, in Kavala Greece

\subsection{Measurement units}

The measurement of trace concentrations of gases can be expressed in several different ways in literature. Parts per million (ppm) can be expressed by volume or by mass which is the main source of confusion. For example, if a pie is divided into 1 million pieces, then $1 \mathrm{ppm}$ is 1 piece of the pie $\left(1 \times 10^{-6}\right)$. In this case, being a solid, it is ppm by mass. Sometimes ppmv is used to remind us that it is by volume. By volume (e.g. gases), the molecular weight must be considered:

$$
1 \mathrm{ppm} \frac{\mathrm{V}_{\mathrm{m}} \times 1 \mu \mathrm{g} \text { gas }}{\text { M1litre air }}
$$

$\mathrm{V}_{\mathrm{m}}=22.711$ litres $/ \mathrm{mol}=$ standard molar volume of ideal gas at $1 \mathrm{bar}, 273.15 \mathrm{oK}$,

$\mathrm{M}=$ molecular weight of gas

Therefore, comparing grouped pollutants such as VOCs, HC and PM expressed in ppm is not always appropriate since they are made up of many compounds that have varying molecular weights. Parts per billion (ppb), is similar in concept and is $1 \times 10^{-9}$ ( 1 nanogram) per cubic meter, $\mathrm{ng} / \mathrm{m}^{3}$.

The other important unit is $\mu \mathrm{g} / \mathrm{m}^{3}$. It simply expresses, with no ambiguity, the quantity of gas present in a given volume. From the point of view of pollutants as health hazards, ppm is a less relevant measure since equal portion of pollutants (expressed in ppm) do not result in the same health hazard. Table 3 shows the conversion from one unit to the other. 


\begin{tabular}{|c|c|c|c|c|}
\hline Gas & Description & $\begin{array}{l}\text { Molecular } \\
\text { weight }\end{array}$ & $\mathrm{V}_{\mathrm{m}} / \mathbf{M}$ & $\begin{array}{l}\text { (5ppm) } \\
\mu \mathrm{g} / \mathrm{m}^{3}\end{array}$ \\
\hline $\mathrm{CH}_{4}$ & Methane & 16 & 1.4194425 & 3.53 \\
\hline $\mathrm{H}_{2} \mathrm{O}$ & Water Vapour & 18 & 1.2617267 & 3.96 \\
\hline $\mathrm{CO}$ & Carbon monoxide & 28 & 0.8111111 & 6.17 \\
\hline $\mathrm{NO}_{2}$ & Nitrous dioxide & 46 & 0.4937191 & 10.13 \\
\hline $\mathrm{O}_{3}$ & Ozone & 48 & 0.4731475 & 10.57 \\
\hline $\mathrm{C}_{6} \mathrm{H}_{6}$ & Benzene & 78 & 0.2911677 & 17.17 \\
\hline
\end{tabular}

Table 3. Conversion from $5 \mathrm{ppmv}$ to $\mu \mathrm{g} / \mathrm{m}^{3}$ for different compounds

\section{The composition of the atmosphere}

The atmosphere is the sphere of air surrounding the earth. The structure of the atmosphere below $50 \mathrm{~km}$ (50,000 meters) is most important for pollution considerations (See Fig.2). The troposphere comprises the part of atmosphere from ground level up to 11,000 meters. This section is generally characterized by turbulent weather, low ozone $\left(\mathrm{O}_{3}\right)$ levels, high water content $\left(\mathrm{H}_{2} \mathrm{O}\right)$ and a linearly varying temperature from ISA conditions on ground to $-55 \mathrm{C}$ at the limit of its height of $11 \mathrm{~km}$. The atmosphere is relatively dense and approximately $80 \%$ of the atmospheric mass is contained in the troposphere. Approximately half of the solar radiation reaches the surface.

The tropopause is marked by the delineation between the troposphere and the stratosphere. The temperature is a constant $-55 \mathrm{C}$ and it is at $11 \mathrm{~km}$ above the earth's surface (Figure 2). The stratosphere is a region of upper atmosphere stretching from the tropopause $(11 \mathrm{~km})$ to approximately $50 \mathrm{~km}$ from the earth's surface. It is generally characterized by high content of ozone $\left(\mathrm{O}_{3}\right)$ and very low water content $\left(\mathrm{H}_{2} \mathrm{O}\right)$.

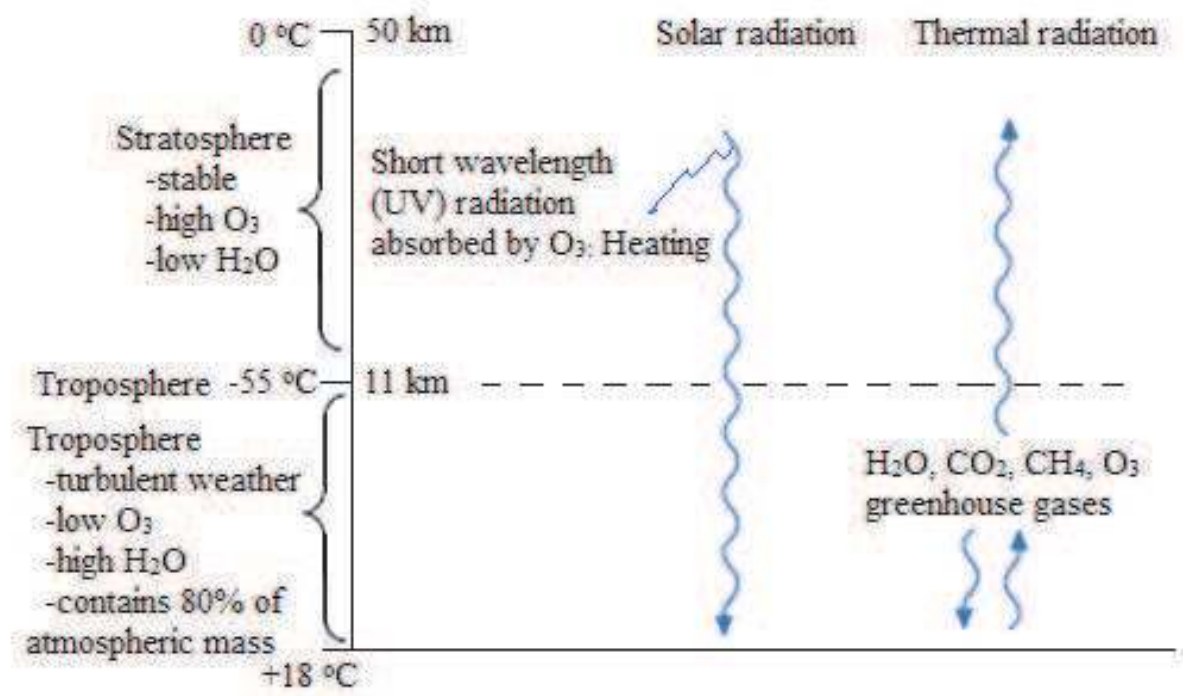

Fig. 2. Structure of the Atmosphere, Radiation and Greenhouse Effect 
It is substantially more stable environment with very little vertical mixing. As ultra-violet solar radiation from the sun is absorbed by ozone $\left(\mathrm{O}_{3}\right)$ when it passes through the stratosphere, the result is a heating of the upper atmosphere up to a maximum of $0 \mathrm{C}$ at 55 $\mathrm{km}$ from the earth's surface.

Ultra-violet (UV) solar radiation is absorbed by ozone $\left(\mathrm{O}_{3}\right)$ as it passes through the atmosphere, heating the upper portion of this region and causing a temperature maximum near $50 \mathrm{~km}$. Below this, some of the solar radiation is reflected, mainly by clouds, and some is absorbed but about half gets through to the surface. This heats the near surface region and results in a second temperature maximum, this time at the surface. The tropopause marks the sharp boundary between the troposphere, in which the temperature drops markedly with height, and the stratosphere, where it generally increases with height. Various atmospheric constituents allow most of the short-wave solar radiation through but absorb and then re-emit the long-wave thermal radiation. This warms the near surface region, the so-called greenhouse effect. Water vapor $\left(\mathrm{H}_{2} \mathrm{O}\right)$, carbon dioxide $\left(\mathrm{CO}_{2}\right)$, methane $\left(\mathrm{CH}_{4}\right)$ and ozone $\left(\mathrm{O}_{3}\right)$ are examples of important "greenhouse gases". A convenient measure of the greenhouse effect of a change in a constituent is provided by the imbalance between solar and thermal radiation at the tropopause when the change in the constituent is suddenly imposed.

At the top of the atmosphere, the solar energy absorbed by the Earth/atmosphere is balanced by the emission of longer wavelength thermal radiation (heat). However, the thermal radiation emitted from the near surface region is absorbed by greenhouse gases, which then re-emit back towards the surface, keeping it warm. The heat lost to space is from levels typically near $5 \mathrm{~km}$ where the air is colder than at the surface.

\subsection{The fixed gases in the atmosphere}

Understanding the natural composition of the earth's atmosphere is necessary to understand the consequences and nature of the substances that are constantly being added to our atmosphere. The main composition of the lower atmosphere is shown in Table 4 and consists mostly of Nitrogen $\left(\mathrm{N}_{2}\right)$ and Oxygen $\left(\mathrm{O}_{2}\right)$ forming up to $99 \%$ of all molecules. The remaining $1 \%$ are trace concentrations of inert gases helium, neon, argon, krypton and xenon and appear in the concentrations specified in Table 4.

\begin{tabular}{|l|l|l|}
\hline Fixed Gas & \% & ppmv \\
\hline Nitrogen $\left(\mathrm{N}_{2}\right)$ & 78.08 & 780,000 \\
\hline Oxygen $\left(\mathrm{O}_{2}\right)$ & 20.95 & 209,500 \\
\hline Helium $(\mathrm{He})$ & 0.0005 & 5 \\
\hline Neon $(\mathrm{Ne})$ & 0.0015 & 5 \\
\hline Argon $(\mathrm{Ar})$ & 0.93 & 9,300 \\
\hline Krypton $(\mathrm{Kr})$ & 0.0001 & 1 \\
\hline Xenon $(\mathrm{Xe})$ & 0.000005 & 0.05 \\
\hline
\end{tabular}

Table 4. Fixed Gases of the Atmosphere

Fixed gases are well mixed in the atmosphere and have stable mixing ratios. The following Table 4 summarizes the key contributors and they are described individually in greater detail below (Sommer et al. 1999). 


\section{Molecular Nitrogen}

Molecular Nitrogen is produced biologically in soils. During the growth of bacteria in anaerobic environments nitrate $\left(\mathrm{NO}_{3}^{-}\right)$is reduced to $\mathrm{N}_{2}$ and small amounts of nitrous oxide gas $\left(\mathrm{N}_{2} \mathrm{O}\right)$ in what is known as "denitrification". The source of nitrate in the soil occurs from a twostep 'nitrification' process from ammonium $\left(\mathrm{NH}_{4}{ }^{+}\right)$. Ammonium is produced in three ways:

i. Naturally from the decomposition of organic material which contains nitrogen atoms

ii. Naturally from a process called nitrogen-fixation occurring in aerobic environments whereby some amounts of $\mathrm{N}_{2}$ are converted to ammonium $\left(\mathrm{NH}_{4}{ }^{+}\right)$

iii. Man-made generation such as fertilizers and other industrial processes

However, this production process of molecular nitrogen is slower than denitrification and, therefore, the concentration of $\mathrm{N}_{2}$ has increased in the atmosphere over time.

Molecular Oxygen

Molecular Oxygen is produced by photosynthesis when $\mathrm{CO}_{2}$ reacts with $\mathrm{H}_{2} \mathrm{O}$ in the presence of solar radiation and chlorophyll found in trees, plants, and algae. A product of this process is carbohydrates of the form $\mathrm{C}_{n} \mathrm{H}_{2 n} \mathrm{O}_{n}$. For example, when $n=6$, glucose is derived:

$$
6 \mathrm{CO}_{2}+6 \mathrm{H}_{2} \mathrm{O}+\mathrm{hv} \stackrel{\text { chlorophyll-1 }}{\longrightarrow} \mathrm{C}_{6} \mathrm{H}_{12} \mathrm{O}_{6}+6 \mathrm{O}_{2}
$$

\subsection{Variable and trace gases in the atmosphere}

Variable gases have volume mixing ratios that can change significantly over time and vary according to location. They are anthropogenic in origin. Natural processes or atmospheric pollution due to human activity in many circumstances can directly affect their concentration levels. The following Table 5 summarizes the key elements of the variable gases.

\begin{tabular}{|l|l|l|}
\hline Variable Gas & \% & ppmv \\
\hline Water Vapor $\left(\mathrm{H}_{2} \mathrm{O}\right)$ & $0.00001-4.0$ & $0.1-40,000$ \\
\hline Carbon Dioxide $\left(\mathrm{CO}_{2}\right)$ & 0.0360 & 360 \\
\hline Methane $\left(\mathrm{CH}_{4}\right)$ & 0.00017 & 1.7 \\
\hline Ozone $\left(\mathrm{O}_{3}\right)$ & $0.000003-0.001$ & $0.03-10$ \\
\hline
\end{tabular}

Table 5. Variable Gases of the Atmosphere

\subsection{Volatile organic compounds and hydrocarbons}

Volatile Organic Compounds (VOCs) are organic volatile chemicals that have high vapor pressure and will easily form vapor at standard ambient temperature and pressure. The term is generally applied to organic aromatic compounds such as benzene, toluene, ethylbenzene, $\mathrm{m} / \mathrm{p}$-xylene and o-xylene, organic solvents, aerosol spray can propellants, fuels (gasoline, kerosene), petroleum distillates. VOCs are also naturally emitted by a number of plants and trees. Many VOCs are flammable. VOCs can be removed with special filtration systems such as activated charcoal systems that absorb organic materials.

VOCs are an important health and environment concern for several reasons: 
i. Some VOCs can be hazardous to health when inhaled. Benzene is a known human carcinogen and toxic. Likewise, Formaldehyde is both an irritant and a sensitizer as well as being toxic

ii. VOCs such as hydrocarbons constitute emissions that instigate photochemical smog.

iii. Some VOCs such as methyl-tertbutyl-ether (MTBE) are gasoline additives that are fairly soluble in water leading to the contamination of water.

iv. VOCs can form particulate matter if condensation forms of the gas

Volatile Organic Compounds, Polycyclic Aromatic Hydrocarbons (PAH) and the carbonyl compounds $\left(\mathrm{CO}, \mathrm{CO}_{2}, \mathrm{CH}_{2} \mathrm{O}\right)$ are the major organic pollutants in the atmosphere. The assessment of VOCs has become a major issue of air quality network monitoring in cities. Toluene and Benzene are the major pollutants. Table 6 gives some examples of common VOCs.

\begin{tabular}{|c|c|c|c|}
\hline \multicolumn{3}{|c|}{ Hydrocarbons } & \multirow{2}{*}{ Other } \\
\hline Aromatic & Aliphatic & Non-aromatic & \\
\hline $\begin{array}{c}\text { Unsaturated } \\
\text { Planar Structure } \\
\begin{array}{c}\text { Cyclic } \\
\text { Noticeable smell }\end{array}\end{array}$ & $\begin{array}{c}\text { Saturated } \\
\text { Tetrahedral } \\
\text { Linear or cyclic }\end{array}$ & $\begin{array}{c}\text { Unsaturated } \\
\text { Chain-like structure } \\
\text { Non-cyclic }\end{array}$ & \\
\hline $\begin{array}{c}\text { Examples: } \\
\text { Bezene }\end{array}$ & $\begin{array}{c}\text { Hydrogenated } \\
\text { products }\end{array}$ & Omega-3 & $\begin{array}{c}\text { Formaldehyde } \\
\text { Liquor }\end{array}$ \\
\hline
\end{tabular}

Table 6. Volatile Organic Compound Classifications

\subsection{Particulate matter (PM)}

The term particulate matter (PM) is used to describe airborne solid particles such as dust, dirt, soot, smoke and/or liquid droplets. Classification by size is based on the aerodynamic diameter because it is a good indicator of the transport and removal of particles from the air and their deposition within the respiratory system. Based on size, urban PM tends to be divided into three principal groups: coarse $\left(\mathrm{PM}_{10}: 2.5 \mu \mathrm{m}-10 \mu \mathrm{m}\right)$, fine $\left(\mathrm{PM}_{2.5}: 1 \mu \mathrm{m}-2.5 \mu \mathrm{m}\right)$ and ultra fine particles $\left(\mathrm{PM}_{0.1}:<0.1 \mu \mathrm{m}\right)$ as shown in Fig. 3. Coarse PM $\left(\mathrm{PM}_{10}\right)$ include geological materials, pollen and sea salt to name a few examples.. Fine PM is derived principally from emissions such as $\mathrm{SO}_{2}, \mathrm{NO}_{x}$ and condensation of VOCs. Ultrafine PM $\left(\mathrm{PM}_{0.1}\right)$ including nanoparticles $\left(\mathrm{PM}_{0.01}\right)$ result from condensed organic carbon or sulfuric acid vapors (Fig. 3).

The particles contained in the $\mathrm{PM}_{10}$ size fraction may reach the upper part of the airways and lung.

\subsection{The green house gases}

Water vapor, Carbon dioxide, and Methane are important greenhouse gases. A greenhouse gas is a gas that readily absorbs infrared radiation. Methane, for example, absorbs infrared radiation emitted by the earth 21 times more efficiently than $\mathrm{CO}_{2}$ (per molecule). However, because mixing ratios are much higher for $\mathrm{CO}_{2}$, it has a more significant impact on the greenhouse effect. 


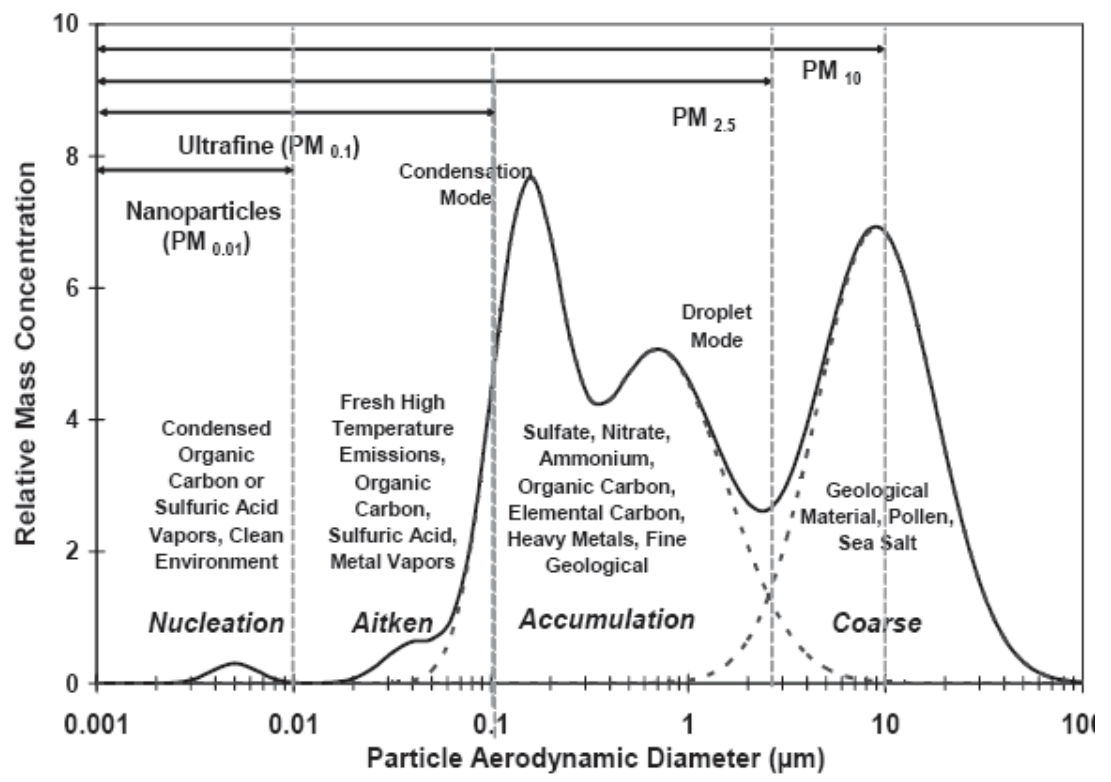

Fig. 3. PM Size chart

It is Jean-Baptiste Fourier who first discovered in 1824 the importance of the greenhouse effect and the overheating of the atmosphere. A little later, the chemist Nicolas-Theodore de Saussure imagined that the emission of $\mathrm{CO}_{2}$ from immense fires could delay the melting of the glaciers. However, towards the end of the XIX century John Tyndall and Olaf Arrhenius discovered the role of the carbon dioxide and the water vapors in this effect. Since then we have learned that there are other gases than the $\mathrm{CO}_{2}$, which contribute to the greenhouse effect, like nitrogen dioxide $\left(\mathrm{NO}_{2}\right)$ and various chlorofluorohydrocarbons (CFC) produced by the industry, such as $\mathrm{CCl}_{3} \mathrm{~F}$ (trichlorofluoromethane) called (CFC-11) and $\mathrm{Cl}_{2} \mathrm{~F}_{2}$ (dichlorodifluoromethane) called CFC-12.

The greenhouse effect is produced by the infrared radiations, which are imprisoned between the earth and the thin layer of the greenhouse gases, which are reflected and heat the earth's surface. These gases let go through the sun's radiations of short wavelengths, such as the visible and ultra -violet, when they are reflected from the surface of the planet and keep the radiations of longer wavelengths, which are the hot infrared radiations that increase the temperature of the surface of the earth. The temperature of the Globe increases almost half a degree $(0.5 \mathrm{C}$ ) per century (from $13.84 \mathrm{C}$ in 1950 to $14.4 \mathrm{C}$ in 2001) and this phenomenon tends to increase rapidly.

\section{The impact of the transport industry on human health}

\subsection{Road transport pollution}

It is only very recently that the full extent of transport's negative impact on health has become clearer. In an ecological audit of the impact of cars on German society ${ }^{52}$ concluded that cars were responsible for 47,000 deaths each year and a range of other, less severe, health impacts. These are summarised in Table 7. 


\begin{tabular}{|c|c|c|}
\hline & Number & Unit \\
\hline deaths from particulate pollution & 25,500 & deaths, pa \\
\hline deaths from lung cancer & 8,700 & “ \\
\hline deaths, from heart attacks & 2000 & “ \\
\hline deaths from summer smog & 1900 & “ \\
\hline \multirow[t]{2}{*}{$\begin{array}{l}\text { deaths from road traffic accidents } \\
\text { (RTAs) }\end{array}$} & 8758 & “ \\
\hline & TOTAL 47,000 & “ \\
\hline serious injuries (RTAs) & 116,456 & injured/pa \\
\hline light injuries (RTAs) & 376,702 & “ \\
\hline chronic bronchitis (adults) & 218,000 & number of illnesses/pa \\
\hline $\begin{array}{l}\text { Invalidity due to chronic } \\
\text { bronchitis }\end{array}$ & 110 & number of invalidates/pa \\
\hline coughs/auswurf & $92,400,000$ & days/year \\
\hline bronchitis (children) & 313,000 & number of illnesses/pa \\
\hline Wiedreholt Husten & $1,440,000$ & number of illnesses/pa \\
\hline $\begin{array}{l}\text { Hospitalisation (breathing } \\
\text { problems) }\end{array}$ & 600 & number of hospitalisations/pa \\
\hline $\begin{array}{l}\text { Hospitalisation (breathing } \\
\text { problems) }\end{array}$ & 9,200 & number of days of care/pa \\
\hline $\begin{array}{l}\text { Hospitalisation (cardiovascular } \\
\text { disease) }\end{array}$ & 600 & hospitalisations/pa \\
\hline $\begin{array}{l}\text { Hospitalisation (cardiovascular } \\
\text { disease) }\end{array}$ & 8,200 & number of says of care/pa \\
\hline Arbeitsunfahigkeit (not cancer) & $24,600,000$ & \\
\hline $\begin{array}{l}\text { Asthma attacks (days with } \\
\text { attacks) }\end{array}$ & $14,000,000$ & days/pa \\
\hline $\begin{array}{l}\text { Asthma attacks (days with } \\
\text { broncho-dilator) }\end{array}$ & $15,000,000$ & days/pa \\
\hline
\end{tabular}

Table 7. Health damage caused by cars, Germany, 1996, annual totals

The volume of death and illness revealed in Table 7 puts the European transport problem into a very serious public health perspective. Transport is a major health problem and should be tackled as much within a public health context as in a traditional transport/roads/highway context. All the deaths and injuries in Table 7 relate to cars and not to lorries or aircraft. Total deaths are about 5 times greater than road traffic accidents deaths.

The total amount of sickness, days in hospital etc. imposes a huge burden on the health services of European countries and this burden is not recovered from those who drive cars. The health impact is a huge human tragedy. 15 million days of use of bronchodilators is a huge problem for many children and many families and the impact on physical activity, 
social activity, enjoyment of outdoor pursuits, community and neighbourhood is incalculable. Health impacts in Europe in the $21^{\text {st }}$ century are the direct equivalent of disease impacts in 19th century cities which then required major re-engineering with clean drinking water and sewage systems. We are still waiting for the $21^{\text {st }}$ century equivalent of this re-engineering to deal with the modern equivalent of widely dispersed sewage.

Road traffic noise and noise from aircraft also create significant health problems (WHO, 1996). These health problems are generally understated in Europe with an implicit assumption on the part of traffic engineers and planners that most people can get used to noise and, in any case, it is only a minor irritation and part of life in an advanced industrial society. This has to be rejected. Noise causes raised blood pressure, cardiovascular disease, a range of psychological problems, sleep disturbance and it damages school age children if they are exposed to noise in a learning environment. WHO (1993) discusses the evidence that supports the contention that children exposed to noise learn less well and have reading abilities lower than is the case for children not in noisy environments. Studies around Heathrow Airport in SE England also point to damage to children living near the airport and under flight paths.

Studies of individual exposure to pollution show that car occupants are exposed to 2-4 times as much pollution from vehicles as are cyclists ${ }^{53}$. This finding is in some ways counterintuitive and surprising but is the result of cars following a very similar path through traffic to that followed by all other cars and effectively driving in a "tunnel of pollution". This raises the very interesting and important conclusion that the car itself damages the health of car occupants. The conventional view is that cars are safer and more pleasant than cycling (presumed to be a dangerous activity). Scientific research shows that this is not the case and the growth of car use in Europe (especially the increase in the number of children carried around by car) represents a significant public health problem which is at least an example of direct correspondence between perpetrator and victim. Those that cause the problem suffer the consequences of that problem. The fastest increase occurred between 1950 and 2000, which is due to human activity.

\subsection{Aviation pollution}

Commercial aviation is experiencing dramatic growth in regions throughout the world, including North America and the United States. However, airport development has not kept pace with increases in aviation activity and the problem is now acute in the United States. In 1996 the Federal Aviation Administration (FAA) Administrator identified lack of airport capacity as the "single most important constraint" to realizing forecast rates of growth throughout the aviation industry. Funding is one problem. The annual shortfall between funds needed for airport development and total funds available is difficult to determine but has been estimated at more than $\$ 4$ billion annually in recent years. A second problem is the rapid pace of change in aviation technologies. Changes in the design and construction of airfield and landside facilities will be necessary to accommodate the larger aircraft that will enter service and the new navigation and air traffic control systems that will be deployed in the near future.

According to IPCC, in 2000 aviation was responsible for 3\% of carbon dioxide emissions due to the total burning of fossil fuel and $13 \%$ of that associated with transport. However, the total greenhouse impact was more important than this would suggest. Since the vast majority of the flights were subsonic and therefore in the $9-13 \mathrm{~km}$ height range, the 
emissions of oxides of nitrogen led, on average, to an increase in ozone as well as a decrease in methane.

Innovative planning approaches are essential to timely development of new airport facilities, and environmental documentation is a key component of the planning process. Federal actions (e.g., funding, approvals) in connection with proposed airport development often require environmental review pursuant to the National Environmental Policy Act (NEPA) and the implementing guidelines of the Council on Environmental Quality and the FAA, which is in the process of updating its Airport Environmental Handbook (Order 5050.4A). In addition to NEPA, a number of states have enacted statutes that mandate evaluation of the potentially significant environmental impacts of development, including airport projects. Beyond compliance with NEPA and state environmental review statutes, airport development proposals may trigger additional analytic requirements that must be carried out in parallel or sequential processes, for example, air quality assessments pursuant to the Environmental Protection Agency (EPA) General Conformity Rule and historic resource documentation pursuant to Section 106 of the National Historic Preservation Act of 1966. Environmental analyses for airport development projects are increasingly subject to technical, political, and ultimately legal scrutiny. More and more often, challenges are raised as to the adequacy of NEPA and state environmental documents as well as studies supporting related determinations by lead agencies or agencies with jurisdiction or special expertise (Health Canada 2005).

The main environmental concerns associated with aircraft are:

- Climate change

- $\quad$ stratospheric ozone reduction, leading to increased surface UV radiation

- regional pollution - changes in tropospheric chemistry for tens to hundreds of kilometres downwind of the airport. In particular, emissions of oxides of nitrogen in air increase ozone

- local pollution - both noise and decreased air quality caused by aircraft and also by the associated ground transportation.

There is no doubt that both local pollution and regional pollution are very serious issues. It is thought that European Directives on permitted levels of oxides of nitrogen may limit the expansion of some airports ( Filliger et al 1999). Concern has been expressed to us that the techniques for assessment of the impact of aircraft emissions on both local and regional air quality are poorly developed and that the available modeling tools are in general inadequate. This issue needs addressing urgently, especially in the light of the recent consultation documents on regional airport development. However, the focus here is on the possible larger-scale impacts of aviation, on surface UV radiation through changes in atmospheric ozone and on climate.

\subsection{Key pollutants}

The main types of pollution linked to aviation and airport operations originate from aircraft, ground-support equipment (GSE), external traffic related to airport activity and industrial parks. Aircraft operations are related primarily to pollution such as carbon monoxide and dioxide, nitrogen oxides, oxides of sulfur, water vapor, hydrocarbon trace pollutants such as benzene and particulate matter consisting mainly of sulfate and soot. These emissions alter the chemical composition of the atmosphere in a variety of ways, both directly and 
indirectly. On the larger-scale, sulfur oxides in aircraft emissions are important only as a source of particles.

The unique feature of these emissions is that the majority of them occur far above the Earth's surface. Subsonic aircraft generally cruise in an altitude range of $9-13 \mathrm{~km}$, close to the tropopause, the sharp transition between the troposphere and the stratosphere (see Fig. 1). The troposphere is the region in which the turbulent motions and precipitation related to weather occur. In contrast the stratosphere is relatively stable and the vertical motions in it are generally sufficiently small compared with the horizontal motions that the air travels almost horizontally (Filliger P et al 1999).

\subsection{Avition and the atmosphere}

The impact of aircraft emissions can be very different depending whether they are in the upper troposphere or the lower stratosphere. Both the abundance of trace gases and the dominant chemical composition and associated chemical reactions are very different in the two regions. In particular water vapour content is relatively high in the troposphere and low in the stratosphere, whereas ozone levels are much higher in the stratosphere. Stratospheric ozone absorbs radiation from the sun. This leads to a heating profile in the stratosphere that determines its character, and also protects life at the surface from the harmful effects of the UV radiation.

The height of the troposphere varies with latitude. In the tropics the tropopause is higher than the normal range of subsonic cruise altitudes but in Polar Regions it is usually at the lower end of this range. Whether an aircraft cruises in the upper troposphere or the lowermost stratosphere depends on its location, the weather and the time of year. Supersonic aircraft typically cruise at levels in the range $17-20 \mathrm{~km}$, which is always in the stratosphere (Filliger et al, 1999). Jet streams are typically located at the tropopause in regions where there are abrupt transitions in the horizontal between the troposphere and the stratosphere. Since eastward-flying aircraft are often routed in the strong westerly winds in jet stream regions to save fuel and time, they often fly close to this almost vertical tropopause. The dominant physical and chemical processes differ between the troposphere and stratosphere, as do the time-scales for transporting air between regions. Water vapor added by any human activity in the troposphere is soon lost through mixing and precipitation processes, whereas at $20 \mathrm{~km}$ it persists and moves slowly towards the pole.

A "conservative gas" is one that becomes well mixed throughout the atmosphere so that the point of emission is irrelevant for its impact on climate. The carbon dioxide produced by the combustion of kerosene in aircraft engines behaves as a conservative gas and so becomes well mixed. However, oxides of nitrogen, produced by high temperature burning in the engine, are rapidly involved in chemical reactions that lead to changes in both ozone and ambient methane. These reactions are complex and sensitive. Ozone is generally produced by oxides of nitrogen in the troposphere and destroyed by it in the lower stratosphere. Since the lifetime of ozone is relatively short, its aircraft-induced increase or decrease is restricted in both the vertical and the horizontal. The lifetime of methane, however, is sufficiently long that the reduction in it produced by the emitted oxides of nitrogen becomes distributed throughout the atmosphere. In the troposphere the amount of water vapor emitted in aircraft exhaust is negligible compared with the pre-existing concentrations in the atmosphere. However, along with the particles emitted, the water vapor can lead to condensation trails, some of which can persist for hours and perhaps trigger the 
development of cirrus clouds. Subsequent cirrus cloud may also be further influenced by particles emitted by aircraft (Samet et al. 2000).

\section{Exposure to various air pollutants and health effects}

\subsection{Clean air}

Clean air is the symbol of life for humans, animals and vegetation and forms the basis of the food processing mechanisms of all these three life-borne species. Oxygen is the active ingredient in the air that reacts with food supplies by oxidizing them or burns them in various animal and vegetable tissues to maintain the balance of life. The remainder of the fixed gases (nitrogen and inert gases) does not react with the food supply. Damage to the food processing mechanism impacts growth and reproduction and, therefore, the future of life. The variable gases can have a direct effect on the quality of air necessary to maintain the food chain mechanisms. Pollution and toxic chemicals can have a detrimental effect on the balance of life and the food chain.

The chemicals that are poisoning our environment are numerous. They change the composition of the atmospheric air. In addition, there are traces of solid materials $\left(\mathrm{PM}_{0.1-0.01}\right.$, $\mathrm{PM}_{2.5}, \mathrm{PM}_{10}$ ) in the air that are equally toxic - usually metal oxides and other solid compounds. Species that breathe air to burn food with oxygen also inhale the toxic chemicals that interact or react with the animal tissues. Lungs, in particular, are susceptible to such damage leading to symptoms of pulmonary diseases that can range from acute irritations to chronic illnesses or death.

Toxic substances can also work their way into the blood stream and cause cardiovascular diseases. It is also known that chemicals may damage hemoglobin and react with tissues such as breast, lung and heart tissues and cells or constituents of cells such as proteins, nucleic acids, membranes such as lipids, phospholipids, and carbohydrates. These possible chemical alterations in the above organs and molecules can lead to other diseases such as cancers and osteoporosis.

Today, people agree that the treasures of the earth are finite and that the biosphere is vulnerable. Studies indicate that $80 \%$ of all materials produced by companies become trash within six months ${ }^{36}$. Until now, our environment has been able to cope with this massive influx of pollution but we are starting to see its limitations of absorbing. The time is rapidly approaching where we must make dramatic changes in the way we manage our environment to avoid drastic consequences to future generations. Increased earth temperature caused by the greenhouse effect will facilitate incubation of bacteria and lead to increases in diseases. Flooding or droughts will also lead to poor hygiene for millions of humans and produce other diseases. As recent catastrophes such as SARS and the poultry viruses demonstrated, humans halfway across the globe in well-developed, western nations are equally susceptible to the transfer of these diseases. Therefore, pollution and environmental management are issues that must be addressed by the developed world.

The results of epidemiological studies can be applied to current air quality statistics to estimate the magnitude of the impact of air pollution on health. The World Health Organization (WHO) produced meta-analyses for the effects on mortality and morbidity of a number of pollutants (WHO, 1997). Their effect estimates have been used by others to calculate aspects of the burden of poor health attributable to pollution. For example, in the 
UK, COMEAP (the UK Department of Health's Committee on the Medical Effects of Air Pollutants) calculated that PM10 was associated with 8,100 deaths brought forward and with 10,500 emergency hospital respiratory admissions (brought forward and additional) in urban areas of Great Britain. The corresponding figures for $\mathrm{SO}_{2}$ were 3,500 deaths brought forward and 3,500 early and extra hospital admissions. The effects of ozone were 700 deaths and 500 admissions if there is no health effect below 50ppb, but 12,500 and 9,900 if there is no threshold. Our own studies have demonstrated that high levels of toxic air pollution can be correlated to increased mortality (Theophanides, M . et al. 2002, 2007).

\subsection{Exposure assessments}

Several empirical methods have been devised to quantify the effect of pollution on mortality and morbidity. The WHO has Meta-Analysis for the effects on mortality and morbidity of a number of pollutants $(\mathrm{WHO}, 1997)$ for $\mathrm{PM}_{10}, \mathrm{SO}_{2}, \mathrm{O}_{3}$. Furthermore, the WHO and is increasingly leaning toward the conclusion, substantiated by supporting research, that for some pollutants, there is no threshold below which is deemed safe. At the very least, increasingly sensitive epidemiological study designs have identified adverse effects from air pollution at increasingly lower levels. For the time being, linear models are being used for which there is no lower threshold (WHO, 2003).

In short-term studies, elderly subjects, and subjects with pre-existing heart and lung disease were found to be more susceptible to effects of ambient PM on mortality and morbidity. In panel studies, asthmatics have also been shown to respond to ambient PM with more symptoms, larger lung function changes and with increased medication use than nonasthmatics. In long-term studies, it has been suggested that socially disadvantaged and poorly educated populations respond more strongly in terms of mortality. PM also is related to reduce lung growth in children. No consistent differences have been found between men and women, and between smokers and non-smokers in PM responses in the cohort studies. (WHO, 2003)

\subsection{Quantification of effects}

The quantification of health effects has become increasingly important in the development of air quality policy. For such analyses it is important to have accurate information on the concentration-response relationships for the effects investigated, i.e. on the relationship between the level of air pollution and the effect on health. A quantitative meta-analysis of peer-reviewed European studies was therefore conducted to obtain summary estimates for certain air pollutants and health effects. The data for these analyses came from a database of time-series studies developed at St George's Hospital Medical School at the University of London. The meta-analysis was performed at St George's according to a protocol approved in advance by a WHO Task Group. Using data from several European cities, the analysis confirmed statistically significant relationships between mortality and levels of PM and ozone in ambient air. Updated risk coefficients in relation to ambient exposure to PM and ozone were obtained for all-cause and cause-specific mortality and hospital admissions for respiratory and cardiovascular causes. Some results are shown in Fig.4. The meta-analysis also included a thorough assessment of so-called publication bias. Fig. 4 shows that $\mathrm{PM}_{2.5}$ presents the high mortality risk for an increase in concentration of this pollutant. The most susceptible cause of mortality is cardiovascular deaths. 


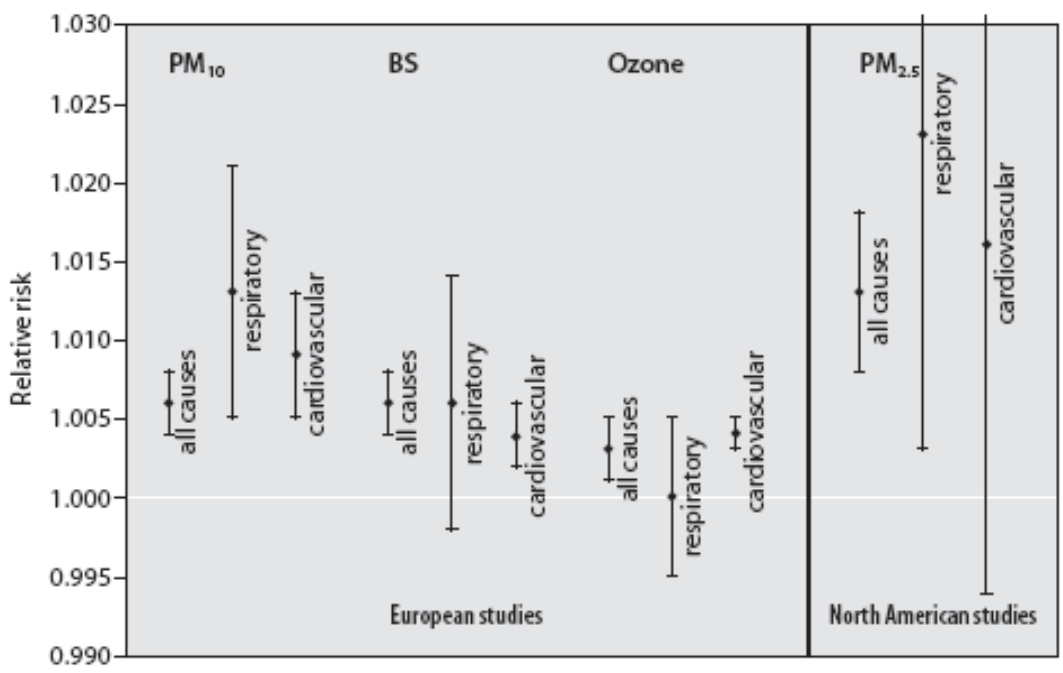

Fig. 4. Probability of mortality risks as a result of a $10-\mu \mathrm{g} / \mathrm{m}^{3}$ increase of a pollutant

The WHO has estimated that in Europe 100,000 death are due to air pollution each year. Studies by the Canadian government have concluded that yearly deaths due to air pollution $\left(\mathrm{CO}, \mathrm{NO}_{2}, \mathrm{SO}_{2}, \mathrm{PM}, \mathrm{O}_{3}\right)$ from anthropogenic sources are 1,800 for short-term exposure and 4,200 for long-term exposure (Mcdonnell, w.f. et al. 2000).

\subsection{Health effects due to particulate matter (PM)}

The effects of short-term exposure to PM have been documented in numerous time-series studies many of them conducted in Europe (Rita Rita K. Seethaler et al 2003); these indicated large numbers of outcomes, such as attributable deaths and hospital admissions for cardiovascular and respiratory conditions. Both short-term (24 hours) and long-term (annual average) guidelines are therefore recommended. The WHO defines the principal short and long-term health effects attributed to Particulate Matter according to Table 8:

\begin{tabular}{|l|l|}
\hline Short-Term & Long-Term \\
\hline Lung inflammatory reactions & Increase in lower respiratory symptoms \\
Respiratory symptoms & Reduction in lung function in children \\
Adverse effects on the: & Increase in chronic obstructive \\
Increase in medication usage & Reduction in lung function in adults \\
Increase in hospital admissions & Reduction in life expectancy, owing \\
Increase in mortality & \\
\hline
\end{tabular}

Table 8. Health Effects due to PM

Fig. 5 shows schematically where particles are deposited in the respiratory tract, depending on their size. Smaller particles (in particular $\mathrm{PM}_{2.5}$ ) penetrate more deeply into the lung and may reach the alveolar region. Ultrafine particles contribute only slightly to $\mathrm{PM}_{10}$ mass but may be important from a health point of view because of the large numbers and high surface area. They are produced in large numbers by combustion (especially internal 
combustion) engines. As stated above, PM in ambient air has various sources. In targeting control measures, it would be important to know if PM from certain sources or of a certain composition gave rise to special concern from the point of view of health, for example owing to high toxicity.

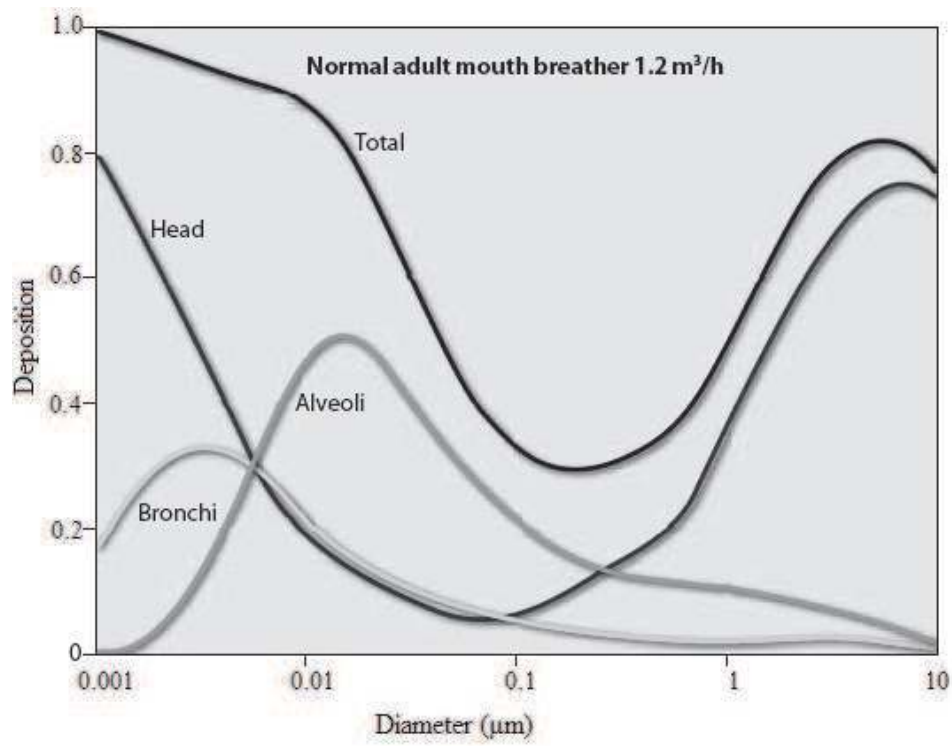

Fig. 5. Respiratory tract deposition probability of inhaled particles

The few epidemiological studies that have addressed this important question specifically suggest that combustion sources are particularly important for health. Toxicological studies have also pointed to primary combustion-derived particles as having a higher toxic potential. These particles are often rich in transition metals and organic compounds, and also have a relatively high surface area. By contrast, several other single components of the PM mixture (e.g. ammonium salts, chlorides, sulfates, nitrates and wind-blown dust such as silicate clays) have been shown to have a lower toxicity in laboratory studies (Schwartz, J. et al. 1996).

Despite these differences found among constituents studied under laboratory conditions, it is currently not possible to quantify the contributions from different sources and different PM components to the effects on health caused by exposure to ambient PM. Nevertheless, it seems reasonable to include in abatement efforts those sources/constituents that have been shown to be critical, such as emissions from diesel engines.

Many studies have found that fine particles (usually measured as $\mathrm{PM}_{2.5}$ ) have serious effects on health, such as increases in mortality rates and in emergency hospital admissions for cardiovascular and respiratory reasons. Thus there is good reason to reduce exposure to such particles. Coarse particles (usually defined as the difference between $\mathrm{PM}_{10}$ and $\mathrm{PM}_{2.5}$ ) seem to have effects on, for example, hospital admissions for respiratory illness, but their effect on mortality is less clear. A few studies suggest that fine PM is more biologically active than coarse PM (defined as particles between 2.5 and $10 \mu \mathrm{m}$ in size) (Klemm, et al 2000; Schwartz, J. \& Neas L. M. 2000; R.W. Atkinson et al., 2000; F. Dominici et al 2007). 
Nevertheless, there is sufficient concern to consider reducing exposure to coarse particles as well as to fine particles. Up to now, coarse and fine particles have been evaluated and regulated together, as the focus has been on $\mathrm{PM}_{10}$. However, the two types have different sources and may have different effects, and tend to be poorly correlated in the air. The systematic review therefore recommended that consideration be given to assessing and controlling coarse as well as fine PM. Similarly, ultrafine particles are different in composition, and probably to some extent in effect, from fine and coarse particles.

\begin{tabular}{|c|c|c|c|}
\hline Annual mean level & $\begin{array}{l}\mathrm{PM}_{10} \\
\left(\mu \mathrm{g} / \mathrm{m}^{3}\right)\end{array}$ & $\begin{array}{l}\mathrm{PM}_{2.5} \\
\left(\mu \mathrm{g} / \mathrm{m}^{3}\right)\end{array}$ & Basis for the selected level \\
\hline $\begin{array}{l}\text { WHO interim target-1 } \\
\text { (IT-1) }\end{array}$ & 70 & 35 & $\begin{array}{l}\text { These levels are estimated to be } \\
\text { associated with about } 15 \% \text { higher } \\
\text { long-term mortality than at AQG }\end{array}$ \\
\hline $\begin{array}{l}\text { WHO interim target-2 } \\
\text { (IT-2) }\end{array}$ & 50 & 25 & $\begin{array}{l}\text { In addition on the other health } \\
\text { benefits, these levels lower risk of } \\
\text { premature mortality by approximately } \\
6 \%[2-11 \%] \text { compared to WHO-IT1 }\end{array}$ \\
\hline $\begin{array}{l}\text { WHO interim target-3 } \\
\text { (IT-3) }\end{array}$ & 30 & 15 & $\begin{array}{l}\text { In addition on the other health } \\
\text { benefits, these levels lower risk of } \\
\text { premature mortality by approximately } \\
6 \%[2-11 \%] \text { compared to WHO-IT2 } \\
\text { levels }\end{array}$ \\
\hline $\begin{array}{l}\text { WHO Air quality } \\
\text { guidelines (QAG) }\end{array}$ & 20 & 10 & $\begin{array}{l}\text { These are the lowest levels at which } \\
\text { total, cardiopulmonary and lung } \\
\text { cancer mortality have been shown to } \\
\text { increase with more than } 95 \% \\
\text { confidence in response to } \mathrm{PM}_{2.5} \text { in the } \\
\text { ACS study. The use of } \mathrm{PM}_{2.5} \text { guideline } \\
\text { is preferred. }\end{array}$ \\
\hline
\end{tabular}

Table 9. Air Quality guidelines for PM (annual)

Nevertheless, their effect on human health has been insufficiently studied to permit a quantitative evaluation of the risks to health of exposure to such particles. Multi-city studies of 29 cities in Europe and 20 cities in the United States (Health Effects Institute, 2004) reported short-term mortality effects for PM10 of $0.62 \%$ and $0.46 \%$ for every $10 \mu \mathrm{g} / \mathrm{m}^{3}$ respectively. A meta-analysis of 29 cities from outside Western Europe and North America reported an effect of $0.5 \%$. A meta-analysis confined to Asian cities reported an effect of $0.49 \%$. This suggests that the health risks for PM10 are likely to be similar in cities in developed and underdeveloped countries at around $0.5 \%$. Therefore, a concentration of 150 $\mathrm{\mu g} / \mathrm{m}^{3}$ would relate to roughly a $5 \%$ increase in daily mortality, an impact that would be of significant concern. Tables 9 and 10 illustrate the WHO guidelines for two different averaging times. 


\begin{tabular}{|c|c|c|c|}
\hline 24-hour mean level* & $\begin{array}{c}\mathrm{PM}_{10} \\
\left(\mu \mathrm{g} / \mathrm{m}^{3}\right)\end{array}$ & $\begin{array}{c}\mathrm{PM}_{2.5} \\
\left(\mu \mathrm{g} / \mathrm{m}^{3}\right)\end{array}$ & Basis for the selected level \\
\hline $\begin{array}{l}\text { WHO interim } \\
\text { target-1 (IT-1) }\end{array}$ & 150 & 75 & Based on published risk \\
\hline $\begin{array}{l}\text { WHO interim } \\
\text { target-2 (IT-2)* }\end{array}$ & 100 & 50 & $\begin{array}{l}\text { Based on published risk coefficients } \\
\text { from multicentre studies and meta- } \\
\text { analyses (about } 2.5 \% \text { increase in short- } \\
\text { term mortality over AQG }\end{array}$ \\
\hline $\begin{array}{l}\text { WHO interim } \\
\text { target-3 }(\text { IT- } 3)^{* *}\end{array}$ & 75 & 37.5 & $\begin{array}{l}\text { About } 1.2 \% \text { increase in short-term } \\
\text { mortality over AQG }\end{array}$ \\
\hline $\begin{array}{l}\text { WHO Air quality } \\
\text { guidelines (AQG) }\end{array}$ & 50 & 25 & $\begin{array}{l}\text { Based on relation between 24-hour and } \\
\text { annual PM level }\end{array}$ \\
\hline
\end{tabular}

Table 10. Air Quality guidelines for PM (24-hr ), *99th percentile (3 days/year), ** for management purpose, based on annual average guideline values; precise number to be determined on basis of local frequency distribution of daily means

\subsection{Health effects due to nitrous oxide $\left(\mathrm{NO}_{\mathrm{x}}\right)$}

$\mathrm{NO}_{2}$ acts mainly as an irritant affecting the mucosa of the eyes, nose, throat, and respiratory tract. Extremely high-dose exposure (as in a building fire) to $\mathrm{NO}_{2}$ may result in pulmonary edema and diffuse lung injury. Continued exposure to high $\mathrm{NO}_{2}$ levels can contribute to the development of acute or chronic bronchitis. Low level $\mathrm{NO}_{2}$ exposure may cause increased bronchial reactivity in some asthmatics, decreased lung function in patients with chronic obstructive pulmonary disease and increased risk of respiratory infections, especially in young children.

\begin{tabular}{|l|l|}
\hline \multicolumn{1}{|c|}{ Short-Term } & \multicolumn{1}{c|}{ Long-Term } \\
\hline $\begin{array}{l}\text { Effects on pulmonary function, particularly } \\
\text { in asthmatics }\end{array}$ & Reduction in lung function \\
\hline $\begin{array}{l}\text { Increase in airway allergic inflammatory } \\
\text { reactions }\end{array}$ & $\begin{array}{l}\text { Increased probability of respiratory } \\
\text { symptoms }\end{array}$ \\
\hline Increase in hospital admissions & \\
\hline Increase in mortality & \\
\hline
\end{tabular}

Table 11. Health Effects due to $\mathrm{NO}_{\mathrm{x}}$ (Finlayson - Pitts \& Pitts 1999)

Guidelines are established as follows (WHO, 2005):

$\mathrm{NO}_{2}$ concentration: $40 \mu \mathrm{g} / \mathrm{m}^{3}$ for annual mean,

and $\mathrm{NO}_{2}$ concentration: $200 \mu \mathrm{g} / \mathrm{m}^{3}$ for 1-hour mean

Effects of $\mathrm{NO}_{2}$ are more difficult to isolate independently because $\mathrm{NO}_{2}$ is an important constituent of combustion-generated air pollution and is highly corelated with other primary and secondary combustion products. No mortality or illness statistics can be associated yet based on lack of evidence. 


\subsection{Health effects due to ozone $\left(\mathrm{O}_{3}\right)$}

Recent epidemiological studies have strengthened the evidence that there are short-term $\mathrm{O}_{3}$ effects on mortality and respiratory morbidity and provided further information on exposure response relationships and effect modification. Based on a meta-analysis of studies published during the period between 1996 and 2001 on short-term effects of $\mathrm{O}_{3}$ on all non-accidental causes of death in all ages (or older than 65 years), significant increase of the risk of dying (between $0.2 \%$ and $0.6 \%$ per each increase in $10 \mu \mathrm{g} / \mathrm{m}^{3}$ ) was shown (Royal 2007).

The National Morbidity Mortality Air Pollution Study (NMMAPS) study, reported a significant effect of $\mathrm{O}_{3}$ during the summer season, of $0.41 \%$ increase in mortality associated with an increase of $10 \mathrm{ppb}\left(20 \mu \mathrm{g} / \mathrm{m}^{3}\right)$ in daily $\mathrm{O}_{3}$ "same-day" concentrations. Ozone daily levels were associated with hospital respiratory admissions at all ages in most of the studies using 8-hour measures and also in many of the studies using other averaging periods.

The magnitude of the association was slightly larger than that obtained for mortality ( 0.5 to $0.7 \%$ increases in admissions per increase of $10 \mu \mathrm{g} / \mathrm{m}^{3}$ in $\mathrm{O}_{3}$. Studies on admissions for asthma in children did not find conclusive associations with any $\mathrm{O}_{3}$ measurement (Paul Hawken, et al 1999, Reeves H \& Lenoir F.2005). The effects of long-term exposure to Ozone are much less known. Table 12 provides a summary of health effects related to Ozone. Table 13 presents the WHO guidelines for 8-hr averaging of Ozone concentrations.

\begin{tabular}{|l|c|}
\hline \multicolumn{1}{|c|}{ Short-Term } & \multicolumn{1}{c|}{ Long-Term } \\
\hline Adverse effects on pulmonary function & \multirow{2}{*}{ Reduction in lung function development } \\
\cline { 1 - 1 } Lung inflammatory reactions & \\
\cline { 1 - 1 } Adverse effects on respiratory symptoms & \\
\cline { 1 - 1 } Increase in medication usage & \\
\cline { 1 - 1 } Increase in hospital admissions & \\
\cline { 1 - 1 } Increase in mortality & \\
\hline
\end{tabular}

Table 12. Health Effects due to $\mathrm{O}_{3}$

\begin{tabular}{|l|l|l|}
\hline & $\begin{array}{l}\text { Daily } \\
\text { maximum } \\
\mathbf{8}-\text { hour mean } \\
\left(\mathbf{\mu g} / \mathbf{m}^{3}\right)\end{array}$ & Effects at the selected ozone level \\
\hline High level & 240 & $\begin{array}{l}\text { Significant health effects, substantial proportion of } \\
\text { vulnerable population affected }\end{array}$ \\
\hline $\begin{array}{l}\text { WHO interim } \\
\text { target-1 (IT-1) }\end{array}$ & 160 & $\begin{array}{l}\text { Important health effects, an intermediate target for } \\
\text { populations with ozone concentrations above this level. } \\
\text { Does not provide adequate protection of public health. } \\
\text { Rationale: } \\
\text { Lower level of 6.6-hour chamber exposures of healthy } \\
\text { exercising young adults, which show physiological and } \\
\text { inflammatory lung effects. } \\
\text { Ambient level at various summer camp studies showing } \\
\text { effects on health of children } \\
\text { Estimated 3-5\% increase in daily mortality* (based on } \\
\text { findings of daily time-series studies) }\end{array}$ \\
\hline
\end{tabular}




\begin{tabular}{|l|l|l|}
\hline & & $\begin{array}{l}\text { This concentration will provide adequate protection of } \\
\text { public health, though some health effects may occur } \\
\text { below this level. } \\
\text { Rationale: }\end{array}$ \\
$\begin{array}{l}\text { WHO Air } \\
\text { quality } \\
\text { guidelines } \\
\text { (AQG) }\end{array}$ & $\begin{array}{l}\text { Estimated 1-2\% increase in daily mortality* (based on } \\
\text { findings of daily time-series studies) } \\
\text { Extrapolation from chamber and field studies based on } \\
\text { the likelihood that real-life exposure tends to be } \\
\text { repetitive and chamber studies do not study highly } \\
\text { sensitive or clinically compromised subjects, or children } \\
\text { Likelihood that ambient ozone is a marker for related } \\
\text { oxidants }\end{array}$ \\
\hline
\end{tabular}

Table 13. Ozone Air Quality guidelines, *Deaths attributable to ozone concentrations above estimated baseline of $70 \mu \mathrm{g} / \mathrm{m}^{3}$. Based on range of 0.3 to $0.5 \%$ increase in daily mortality for $10 \mu \mathrm{g} / \mathrm{m}^{3}$.

\section{Indoor air quality}

The quality of air inside homes, buildings, schools, day care centers, etc is very important. The quality of the air that we breathe can have important effects on our health and quality of life. However, we breathe all time when we are outdoors or indoors. We are used to thinking of the outdoor environment to be safe from air pollution. It is known that during smog or dusty air people are advised to stay indoors. Yet new research, in particular research for the astronauts from the National Aeronautics and Space Administration (NASA), faced the problem of indoor air pollution and began extensive studies on treating and recycling air in the chambers. These studies lead to the problem of indoor air pollution. They discovered that the indoor environment may be as much as ten times more polluted than the outdoor environment. However, as early as 1950 Dr. T.G. Randolph (Wolverton, 1996) became one of the first medical doctors to link indoor air pollution with allergies and other chronic diseases. Still today millions of people fail to realize the serious nature of the problem. Today people living in cities and in industrialized environments spend as much as $80 \%$ of their lives indoors fail to recognize this problem. Exposure to indoor air pollutants, which are many as we will see later, correlates to an increase in the number of allergic reactions, as well as to chronic diseases due to toxic substances. NASA scientists started to study the development of sustainable indoor ecological life- support facilities. The NASA scientists soon discovered that houseplants could purify air in sealed test-chambers. As many people become concerned about the direct association of indoor environment and their health, the green revolution will grow. If we stress the importance of indoor air quality and to relate our existence to a symbiotic and beneficial relationship with the animals and plants of our nature then we will be closer to our living world.

\subsection{House plants and indoor air quality}

Evidence is given to show how houseplants can become a necessary component of healthy buildings whether houses or offices and how houseplants can improve the indoor air quality. Houseplants are capable of removing toxic chemical vapors. Low relative humidity levels, below 35 percent are also associated with poor IAQ. Frequent colds and allergic 
asthma during the cold winter months are often caused by low relative humidity. Emissions from modern materials used to construct home or office furniture from pressed wood products or fiberboard, which often replace natural wood in building construction, as well as wall- to- wall carpeting are synthetic materials and are held together with glues and resins. Furthermore, a number of electronic devices are found in our homes today, such as radios, televisions, etc. for our pleasure are known to emit various organic compounds. The synthetic materials release hundreds of volatile organic materials (VOCs) into the indoor air. Compounds that may be found in the air of indoor houses, buildings and offices may be formaldehyde, xylene, toluene, benzene, chloroform, alcohols, acetone, etc. Humans are also a source of indoor air pollutants especially in closed and poorly ventilated areas. In addition to carbon dioxide humans release many volatile substances, in the atmosphere, which are called "biofluents", such as, ethyl alcohol, methyl alcohol, acetone, ammonia, etc.

Thus, sealed buildings and synthetic furnishings are the main sources of indoor air pollution a phenomenon known as "sick building syndrome" (SBS) with some common symptoms, i.e. allergies, asthma, eye, nose and throat irritation, fatigue, headache, respiratory congestion, sinus congestion and others. Some also include lung cancer from asbestos exposure.

\subsection{Epidimiologic studies}

The epidemiological study into symptoms among office workers has produced many important results, which are conflicting due to methodologic issues in the interpretation of the epidemiological findings (Mendell, 1993). The environmental factors that were found increased symptoms with air conditioning, carpets, video display terminals, etc. The ventilation rates near or below 10 liters/second/person decreased symptoms. Personal factors, such as female gender, job stress/dissatisfaction and allergies/asthma were also studied and showed increased symptoms with the above factors. The evidence suggested that work related symptoms among office workers were relatively common. Indoor exposure and problems due to this exposure could be reduced if prevention of building related symptoms may be eliminated with appropriate design, operation and maintenance practices, such as ventilation rates (Zuraimi, 2010).

In another study microbial indoor air quality and respiratory symptoms of children in schools with visible moisture and mold problems showed that school buildings of concrete/brick developed fungi concentration, but not in wooden school buildings (Meklin et al, 2002). There are more epidemiological studies, which indicate that there are risks associated with elevated air fine particle concentrations (Mullen et al. 2011, Pope \& Dockey, 2006).

Potential health risks may result from environmental exposure to ultrafine particles $(<0.1$ $\mu \mathrm{m}$ diameter) in particular exposure in school classrooms. It was found that average indoor levels were higher when classrooms were occupied than when they were unoccupied due to ultrafine particle concentrations (Mullen et al. 2011).

A multi location indoor study in air settled dust showed abundance of orthophosphate and phthalate esters (Bergh et al. 2011). Both groups of chemicals are semi volatile compounds and they are additives in plastic materials, which are used into indoor environment as industrial chemicals emanating from furniture in general. These chemicals were found in private homes, day care centers, and workplaces in the Stockholm area. The phthalate esters were 10 times higher than the orthophosphate esters. Especially high levels of tributoxyethyl phosphate were found in the day care centers and high levels of diethylhexyl phthalate in dust. 


\section{References}

Atkinson, R.W. et al., (2000) Acute Effects of Particulate Air Pollution on Respiratory Admissions, Am. J. Respir. Crit. Care Med. 164/10, 1860-1866,

Arribas-Monzón, F.; Rabanaque, M.J.; Martos, C.; Abad, J.M.; Alcatá-Nalvaiz, T. \& NavarroElipe, M. (2001) Effects of air pollution on daily mortality in Zaragoza, Spain, 19911995, Salud Pública México. Pp. 43 1-8.

Basu R. \& Samet J. M. (2002) Relation between Elevated Ambient Temperature and Mortality: A Review of the Epidemiologic Evidenc, Epidemiol. Rev., 24(2), 190-202

Bergh, C.; Torgrip, R.; Emenius, G. \& Östman, C. (2011). Organophosphate and phthalate esters in air and settled dust- a multi-location indoor study. Indoor Air; 21; 67-76.

Coull, B.A.; Schwartz, J. \& Wand, MP. (2001). respiratory health and air pollution: additive mixed model analysis, Biostatistics, 2/3; 337-349

Council on Environmental Quality kat Airport Environmental Handbook, Order 5050.4A, National Environmental Policy Act (NEPA). Airports Orders.

Dominici, F. (2002) Invited Commentary: Air Pollution and Health -What Can We Leaarn from a Hierarchical Approach, Am. J. Epidemiol., 155, , 1-15

Dominici, F. et al, (2007). Particulate Air Pollution and Mortality in the United States : Did the Risks Change fron 1987 to 2000, Am. J. Epidem., 166 (8), 880-888,

Filliger P., Puybonnieux-Texier V. and Schneider J. (1999). Health costs due to road trafficrelated air pollution. An impact assessment project of Austria, France and Switzerland. PM10 population exposure. Technical report on air pollution. GVFReport nr 326 - TEH05.

Filleul L, Baldi I., Dartigues J.-F., and Tessier J.-F., Risk factors among elderly for short term deaths related to high levels of air pollution, Occup. Environ. Med., 60(9) 2003, 684-688

Finlayson - Pitts B. J. \& Pitts Jr., J. N., (1999). Chemistry of the Upper and Lower Atmosphere : Theory, Experiments and Applications, Hardcover, Academic Press

Hawken, P.; Lovins, A.B. \& Hunter, L. (1999). Natural Capitalism: Creating the Next Industrial Revolution, Little Brown Company.

Health Effects Institute, 2004, International Oversight Committee, Special reports, Particulate Matter

Health Canada (2005). Estimated Number of Excess Deaths in Canada due To Air Pollution", S. Judek, B. jessiman, D. Stieb, Air Health Effects Division, Health Canada and R. Vet, Meteorological Service of Canada, Environment Canada, April.

Jerrett M., Burnett R. T., Brook J., Kanaroglou P., Giovis C., Finkelstein N., \& Hutchison B. 200. Do socioeconomic characteristics modify the short term association between air pollution and mortality? Evidence from a zonal time series in Hamilton, Canada J. Epidemiol, Community Health, 58(1), 31-40

Judek, S.; jessiman, B. ; Stieb, D. \& Vet, Health R. (2005). Estimated Number of Excess Deaths in Canada due To Air Pollution, Air Health Effects Division, Health Canada Meteorological Service of Canada, Environment Canada, April.

Katsouyanni, K. (2003). Ambient air pollution and health, British Medical Bulletin, 68 143-156.

Klemm, R. J. ET AL. (2000).Is daily mortality associated specifically with fine particles? Data reconstruction and replication of analyses. Journal of the air and waste management association, 50: 1215-1222

Kotzias, D. Human exposure research, Needs and Approaches, $8^{\text {th }}$ FECS Conference. 2003, 13. 
Kunzli N., Medina S., Kaiser R., Quenel P., Horak F. Jr. \& Studnicka M. (2001). Assessment of Deaths Attributable to Air Pollution: Should We Use Risk Estimates based on Time Series or on Cohort Studies? Am. J. Epidemiol., 153, 1050 - 1055

Le Tertre A., Medina S., Samolli E., Forsberg B., Michelozzi P., Boumghar A., Vonk J. M., Bellini A., Atkinson R., Ayres J. G., Sunyer J., Schwartz J., and Katsouyanni K., Short-term effects of particulate air pollution on cardiovascular diseases in eight European cities, J. Epidem. Commun. Health, 56 , 2002, 773-779

Mcdonnell, w.f. et al. (2000). Relationships of mortality with the fine and coarse fractions of long-term ambient PM10 concentrations in nonsmokers. J Exposure Analysis Environmental Epidemiology, 10: 427-436.

Meklin, T.; Husman, T.; Vepsäläinen, T.; Vahteristo, M. Koivisto, J.; Halla-Aho, J.; Hyvärinen, A.; Moschandreas, D. \& Nevalainen, A. (2002). Indoor Air. 12; 175-183.

Mendell, M. (1993). Non-specific symptoms in office workers: A review and summary of epidemiologic literature, Indoor Air. 3; 227-236.

Mullen, N.A.; Bhangar, S.; Hering, S.V.; Kreisberg, N.M. \& Nazarof. W.W. (2011). Indoor Air. Ultrafine particle concentrations and exposures in six elementary school classrooms in northern California. 21; 77-8

Rita K. Seethaler, K. Künzli N., Sommer H., Chanel O., Herry M5, Masson S., Vernaud J-C., Filliger P., Horak F.Jr., Kaiser R., Medina S., Puybonnieux-Texier V., Quénel P., Schneider J., Studnicka M., Heldstab J. (2003). Economic costs of air pollutionrelated health impacts, An Impact Assessment Project of Austria, France and Switzerland, Clean Air E Environmental Quality, Vol. 37, No. 1, 35-43

Reeves H, Lenoir F., Mal de Terre, Editions du Seuil, 2005.

Royal Commission on Environmental Pollution (2007). The Environmental Effects of Civil Aircraft in Flight. 22 March, Report.

Samet, J.M.; Dominici, F.; Curriero, F.C.; Coursac, I. \& Zeger S. L. (2000). Fine particulate air pollution and mortality in 20 U.S. cities 1987-1994. New Eng J Me., 343: 1742-1749

Samoli E., Touloumi G., Zanobetti A., Le Tertre A., Schindler C., Atkinson R., Vonk J., Rossi G., Saez M., Rabczenko D., Schwartz J. \& Katsouyanni K.(2003) Investigating the dose-response relation between air pollution and total total mortality in the APHEA-2 multicity project, Occup Environ Med. 60:977-982

Samet J.M. , Zeger, S.L., Dominici F., Curriero F., Coursac I., Dockery D.W. \& Schwartz J., (2000). The National Morbidity, Mortality, and Air Pollution Study. Part II: Morbidity and mortality from air pollution in the United States. Health Effects Institute. North Andover MA: Flagship Press. 94 Part II:1-82.

Schwartz, J. Dockery, D.W., Neas, L.M. (1996). Is daily mortality associated specifically with fine particles? Journal of the air and waste management association, 46: 927-939

Schwartz, J. \& Neas L. M. (2000) Fine particles are more strongly associated than coarse particles with acute respiratory health effects in schoolchildren. Epidemiology, 11: 6-10

Sommer, H., Seethaler, R., Chanel, O., Herry, M., Masson, S., Vergnaud, J.-C. (1999). Health costs due to road traffic-related air pollution. An impact assessment project of Austria, France and Switzerland. Economic evaluation. Technical report on economy. GVF-Report nr 326 - TEH07 Federal Department for Environment, Transport, Energy and Communications Bureau for Transport Studies, Bern. 
Prepared for the Third World Health Organisation Ministerial Conference of Environment and Health, London, 1999.

Sunyer J. and Basagana X., Particles, and not gases, are associated with the risk of death in patients with chronic obstructive pulmonary disease, Int. J. Epidemiol., 30, 2001; 1138-1140

Theophanides, M.; Anastassopoulou, J. \& Theophanides, T. (2002). A statistical study of disease-related mortalities due to environmental pollutants in Kavala, Greece, In Environmental science and pollution research, $8^{\text {th }}$ FECS Conference on chemistry and the environment, 44 .

Theophanides, T.; Vassilakos, Ch.; Anastassopoulou, J.; Maggos, T.; Hatzianestis, J.. \& Bartzis, I. (2002). Chemical Characterization of VOCs in Nea Karvali area, Kavala, Greece, In Envirommental science and pollution research, $8^{\text {th }}$ FECS Conference on chemistry and the environment, 45-46.

Theophanides, M.; Anastassopoulou, J.; Vasilakos, Ch.; Maggos, Th. \& Theophanides, T. (2007). Mortality and Pollution in Several Greek Cities, J. Envir. Scien Health, Part A, 42/6; 741-746.

Theophanides, M. \& Theophanides, T. Human environmental engineering and sustainability, in M. Theophanides and T. Theophanides Eds., Environmental Engineering and Economics, ATINER, Athens, Greece, pp. 1-8.

Theophanides, M. \& Anastassopoulou, J. (2009). Simulation of Air Pollution and Health Effects, In: in Environmental Awarness and Management, eds, T. Theophanides and M. Theophanides, ATINER, Athens, Greece, pp. 29-37

Touloumi, G.; Pocock, SJ.; Katsouyianni, K. \& Trichopoulos, D. Short-term effects of air pollutions on daily mortality in Athens: a time- series analysis, Int. J. Epidemiol. 1994, 23 957-967.

The MACBETH project (1999): Monitoring of atmospheric concentrations of benzene in European towns and homes, EU LIFE project 96ENV/IT070

Tunnicliffe W. S., Harrison R.M., Kelly F. J., Dunster C., and Ayres J. G., The effect of sulfurous air pollutant exposures on symptoms, lung function, exhaled nitric oxide, and nasal epithelial lining fluid antioxidant concentrations in normal and asthmatic adults, Occup. Environ. Med. 60(11), 2003, 15-15

Tobias, A.; Saez, M.; Daniels, M. J,; Dominici, F.; Zeger S. L. \& Samet J. M., RE (2001). Estimating Particulate Matter - Mortality Dose - Response Curves And Threshold Levels: An Analysis Of Daily Time - Series For The 20 Largest Us Cities, Am. J. Epidemiol., 153, 1027 - 1028

WHO (2002). Systematic review of health aspects of AQ Europe. An overview of the St. George's project. A systematic review of the epidemiological literature on the shortterm health effects of outdoor air pollution, St. George's Hospital, London, United Kingdom.

Wolverton, B.C. (1996).How to Grow Fresh Air: Houseplants that purify your home or office, Penguin Books.

Yang, C-Y.; Chang, C-C.; Chuang, H-Y.; Tsai, S-S.; Wu, T-N.; Ho, C-K. Relationship between air pollution and daily mortality in a subtropical city: Taipei, Taiwan, Environm. Int. 2004, 30 519-523.

Zuraimi, M. (20101). Is ventilation dust useful? A review of scientific evidence. Indoor Air. $20 ; 445-457$. 


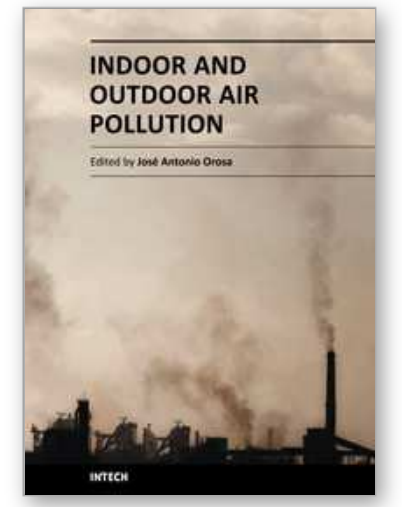

\author{
Indoor and Outdoor Air Pollution \\ Edited by Prof. JosÃ@ Orosa
}

ISBN 978-953-307-310-1

Hard cover, 126 pages

Publisher InTech

Published online 22, September, 2011

Published in print edition September, 2011

Air pollutants are continuously released from numerous sources into the atmosphere. Several studies have been carried out on the quantification of pollutants and their consequences on public health. Identification of the source characteristics of air pollution is an important step in the development of regional air quality control strategies. Air quality is a measure of the degree of ambient atmospheric pollution. Deterioration and damage to both public health and environment due to poor air quality have been recognized at a legislative and international level. In consequence, indoor and outdoor air quality must also be considered. This book tries to reveal different points of view of the wide concept of air quality in two different sections. In this context, there will be an initial introductory chapter on the main concepts of air quality, following which there will be real case studies on outdoor and indoor air quality with an aim to provide a guideline for future standards and research works.

\title{
How to reference
}

In order to correctly reference this scholarly work, feel free to copy and paste the following:

Michael Theophanides, Jane Anastassopoulou and Theophile Theophanides (2011). Air Polluted Environment and Health Effects, Indoor and Outdoor Air Pollution, Prof. JosÃ@ Orosa (Ed.), ISBN: 978-953-307-310-1, InTech, Available from: http://www.intechopen.com/books/indoor-and-outdoor-air-pollution/air-pollutedenvironment-and-health-effects

\section{INTECH}

open science | open minds

\author{
InTech Europe \\ University Campus STeP Ri \\ Slavka Krautzeka 83/A \\ 51000 Rijeka, Croatia \\ Phone: +385 (51) 770447 \\ Fax: +385 (51) 686166 \\ www.intechopen.com
}

\author{
InTech China \\ Unit 405, Office Block, Hotel Equatorial Shanghai \\ No.65, Yan An Road (West), Shanghai, 200040, China \\ 中国上海市延安西路65号上海国际贵都大饭店办公楼 405 单元 \\ Phone: +86-21-62489820 \\ Fax: +86-21-62489821
}


(C) 2011 The Author(s). Licensee IntechOpen. This chapter is distributed under the terms of the Creative Commons Attribution-NonCommercialShareAlike-3.0 License, which permits use, distribution and reproduction for non-commercial purposes, provided the original is properly cited and derivative works building on this content are distributed under the same license. 